\title{
Bio-Monitoring of Air Quality Using Leaves of Tree and Lichens in Urban Environments
}

\author{
M. Maatoug, K. Taïbi, A. Akermi, M. Achir and M. Mestrari \\ Faculty of Natural Sciences, \\ Ibn Khaldoun University, Tiaret \\ Algeria
}

\section{Introduction}

Air pollution is the presence of pollutants in the atmosphere from anthropogenic or natural substances in quantities likely to harm human, plant, or animal life; to damage human-made materials and structures; to bring about changes in weather or climate; or to interfere with the enjoyment of life or property. In developing countries, industrial growth and population increase, together with rising standards of living will probably lead to patterns of motorization that resemble those of industrialized countries. Many urban areas have high concentrations of air pollution sources resulting from human activities; sources such as motor vehicle traffic, power generation, residential heating and industry. Urban air pollution is a major environmental problem in the developing countries of the world. It not only represents a threat to human health and the urban environment, but it can also contribute to serious regional and global atmospheric pollution problems (Maatoug 2010). Motor vehicles are now recognized as the major contributor due to their emissions of suspended particulate matter including heavy metals. Meteorological and topographical conditions affect dispersion and transport of these pollutants, which can result in ambient concentrations that may harm people, structures, and the environment. Air pollution is worse in locations with unfavorable topographical or meteorological characteristics. Meteorological factors such as thermal inversions restrict dispersion of pollutants and result in high ambient pollutant concentrations. Unfavorable topography and wind direction have similar effects.

Current scientific evidence indicates that urban air pollution, which is derived largely from combustion sources, causes a spectrum of health effects ranging from eye irritation to death. Recent assessments suggest that the impacts on public health may be considerable. The health effects of pollutants depend on many factors, including the number and age group of exposed people and their health status, ambient concentrations and types of pollutants, and dose-response functions. Quantifying the magnitude of these pollutants and health impacts in cities worldwide, however, presents considerable challenges owing to the limited availability of information on both effects on health and on exposures to air pollution in many parts of the world. 
Heavy metals in ambient air also originate from emissions from coal combustion and various trace metals-based industries. They are the subject of special attention because of the risks they may pose to human health and dangers associated with their persistence in ecosystems. Chronic sources of trace metals in urban highway have two origins: vehicles and road infrastructures. The pollutants emissions from vehicles are due in part to abrasion and corrosion of materials of vehicle and in other part to the use of different fluids (DelmasGadras, 2000). The two main metallic pollutants emitted, lead and zinc, are mainly found in the exhaust gas and brake linings (75\% of lead content in gasoline is emitted in engine exhaust), but zinc is also present in tires, lubricants and especially in the guardrail (Deletraz, 2002). However, the brakes are an important source of copper. The trace metals are naturally present in soil in small quantities. They are partially released during the degradation of bedrock and form the endogenous pool called pedogeochemical bottom (Baize, 1997). A second pool, more or less important depending on geographic situation and exogenous supplies comes mainly from the industries, transport and agricultural activities (FernandezCornudet, 2006).

\begin{tabular}{|l|c|c|c|}
\hline & Copper & Zinc & Lead \\
\hline Agricultural wastes & $55 \%$ & $61 \%$ & $20 \%$ \\
Municipal wastes & $28 \%$ & $20 \%$ & $38 \%$ \\
Atmospheric deposition & $16 \%$ & $40 \%$ & $40 \%$ \\
\hline
\end{tabular}

Table 1. Percentages of different sources in the annual average land enrichment by heavy metals (Fernandez-Cornudet, 2006).

Biomonitoring is the technique base on use of organisms that have the ability to store and accumulate contaminants in their tissues, "bioaccumulation", under the control of several mechanisms of setting and transfer. This technique has become attractive complement of traditional methods for measurements of air quality. The identification of pollution within sensitive organisms can also allow detection of air quality degradation before it severely affects the biota or humans. Sensitive plants can be real bioindicators of pollution. Urban vegetation can interact, directly and indirectly, with local and regional air quality by altering the urban atmospheric environment. Trees can change local meteorology, alter pollution concentrations in urban areas, and remove gaseous air pollution or intercepting airborne particles. Phytoremediation is a method of environmental treatment that makes use of the ability of some plant species to accumulate certain elements, including heavy metals, in amounts exceeding the nutrition requirements of plants. Some plant species have fairly high specificity towards individual pollutants and can be used to show variations in pollutant concentration, either with time at one place, or from place to place.

Our study constitutes an attempt to evaluate the air quality in semiarid region, Tiaret city, from Algeria. The first aim of this work (case I) was to assess the most frequent atmospheric heavy metal accumulated in leaves of different urban plant species in the context of their usefulness in urban environment as bioindicator or in phytoremediation. In another version of this idea (case II), in order to determine the main source of pollutants from a part and their spatial repartition in the city in the other part (cause of the immobility of urban trees and their heterogeneous repartition), lichens have been used. Lichens have no root system to take up minerals from the substrate on which they grow, and accumulate materials such as 
heavy metals from wet and dry deposition and also they are easy to transplant and transport.

\section{Case I Use of two bioaccumulative plant species (plane on maple leaves Platanus acerofolia and Cypress evergreen Cupressus sempervirens) to assess the impact of heavy metals $(\mathrm{Pb}, \mathrm{Zn}, \mathrm{Cu})$ originated from urban traffic in the city of Tiaret (Algeria)}

Optimal use of plants as a means of investigation of air pollution concerns cases where the path of soil contamination is either nil, negligible or known. This is why most plants used for these studies are mosses and lichens with, among others, to their lack of root system.

Indeed, the major contaminations of plant leaves by heavy metals are of two kinds:

- Diffuse air intakes, by deposition on the aerial parts of plants, according to the bioclimatic conditions (wind, rain ...), the volatility and transport of pollutants. They are deposited on the leaf area of the plant (cuticle and epidermal hairs). This is an external assimilation of metal pollutants. In general, the accumulation of metals is different depending on the plant considered and plant parts analyzed. The levels of pollutants measured recently in leaves are usually higher than those detected in the stems and roots (Kupper et al., 2001).

- Inputs via the ground. The trace metals can be released into the atmosphere and fall again by dry or moist way into soils along road. They are also likely to be deposited on the floor and then be driven by the storm water runoff. The trace metals present in surface water can migrate into the soil during the infiltration of water and contribute to the degradation of soil quality, reaching groundwater and impair water resources (Delmas-Gadras, 2000). In the city of Tiaret, the main contribution to trace metals is done through the atmosphere, including emissions from road traffic.

Edwards (1986) showed that the metal enters the plant through the roots to the leaves, and it is chelated by organic molecules that support it so it does not disturb the functioning of the plant cell. This is an internal assimilation of metal pollutants. The transfer of a trace element from the soil to harvest depends on both parameters related to soil and plant-specific factors. It follows as a kind of meeting between ground supply and plant demand, which are not totally independent. In particular, plant can modify the soil offer by changing, including root exudation of various compounds (protons, complex organic molecules for example), the physical and chemical conditions that govern the solubility of the element on the solid phase and its speciation in solution. This feedback effect of the plant availability of trace elements is currently difficult to quantify (Agency for Environment and Energy Management ADEME, 2005).

As part of this work, the study is focused on the importance of using plants as bio-indicators of airborne contamination by heavy metals issue from road traffic, the important source of contamination in the city. It aims to establish that the leaves of trees growing in urban areas have the potential to serve as indicators for relative quantification of metal air pollution resulting from road traffic. The emissions of $\mathrm{Pb}, \mathrm{Zn}$ and $\mathrm{Cu}$ original traffic are mainly in the form of fine particles which are then collected by the leaf surfaces. 


\subsection{Materials and methods}

\subsubsection{Site selection and plant material}

Five sites were selected in this investigation, four urban sites designated by S1, S2, S3 and S4 are located in the center of Tiaret ${ }^{1}$ where the road sector is important and a control site. Each site consists of six healthy trees, consistent and having substantially the same age. There are three planes on maple leaves (Platanus acerofolia.Willd) ${ }^{2}$ and three evergreen cypresses (Cupressus sempervirens.L) ${ }^{3}$. The control site is away from sources of contamination of air pollution and serves as a reference when comparing with the contaminated sites.

Note that the plane leaves attach and accumulate heavy metals during periods of summer and spring before falling in autumn. However, the cypress leaves accumulate heavy metals throughout the year. These two species are widely grown in the study sites and the concentrations of lead, zinc and copper issues from road traffic were determined in leaves. It was designed to quantify the levels of pollution air by these three metals from the process of bioaccumulation in these species.

It is important to note that the two sites S1 and S2 are located in a steep area assigned a very high traffic where the frequency of braking and idling is extremely important. However, sites S3 and S4 are located in a road sector relatively less important than sites S1 and S2 (Figure 1).

\subsubsection{Samples collection}

For each tree, about fifty shoots were taken from ground level to avoid contamination due to projections from the ground.

The material was taken to limit contamination: without losses or pollution, avoiding the use of tools or containers that may contaminate the sample (tool steel or stainless steel containers whose walls contain pigments of trace elements, such as PVC).

\footnotetext{
${ }^{1}$ The study was conducted in the city of Tiaret, which is located in the northwest of Algeria between the mountainous Tell chain in the north and the mountainous Atlas chain in the south, at an altitude of 980 $\mathrm{m}$ on average. The climate is Mediterranean semi-arid with average annual rainfall of $400 \mathrm{~mm} /$ year. The prevailing winds are from the west and northwest, their average speeds range from 3 to $4 \mathrm{~m} /$ second. The city of Tiaret has over $200 \mathrm{~km}$ of urban roads. Its automobile park contains 6284 vehicles of all types, of which $11 \%$ of them are new cars (National Agency for the Development of territories ANAT, 2005: personnel communication). In 2006, the automobile park of the Wilaya (department) of Tiaret contains 8015 registered vehicles. This park is highly heterogeneous due to the variety of vehicles (individual or utility vehicle, gasoline or diesel, old or recent, etc.).. Of these, new cars (from 0 to 5 years) represent only $11 \%$ of the park, however, the cars of more than 11 years account for $74 \%$. Yet it is precisely these older vehicles are more polluting [10].

2 Hybrid tree between Platanus orientalis and Platanus occidentalis. The plane tree on leaf of maple is a tree commonly reaching $30 \mathrm{~m}$ high. Often planted as an ornamental and alignment tree. Palmately lobed leaves are alternated, with deciduous large stipules and hairy. Leaf hairs are particularly abundant on the underside of young leaves.

${ }^{3}$ Coniferous tree, up to $30 \mathrm{~m}$ high. It was firstly used as an ornamental plant and in public parks, and then it was also used as windbreaks and reforestation. It consists of two distinct varieties: the variety horizontalis with branches almost perpendicular to the trunk and crown basically conic, the variety pyramidalis has a fastigiate crown with branches leaning against the trunk, short or long. The leaves are opposite, evergreen, with small scales of 0.5 to $1 \mathrm{~mm}$, slender, finely serrated and closely applied to the branches.
} 


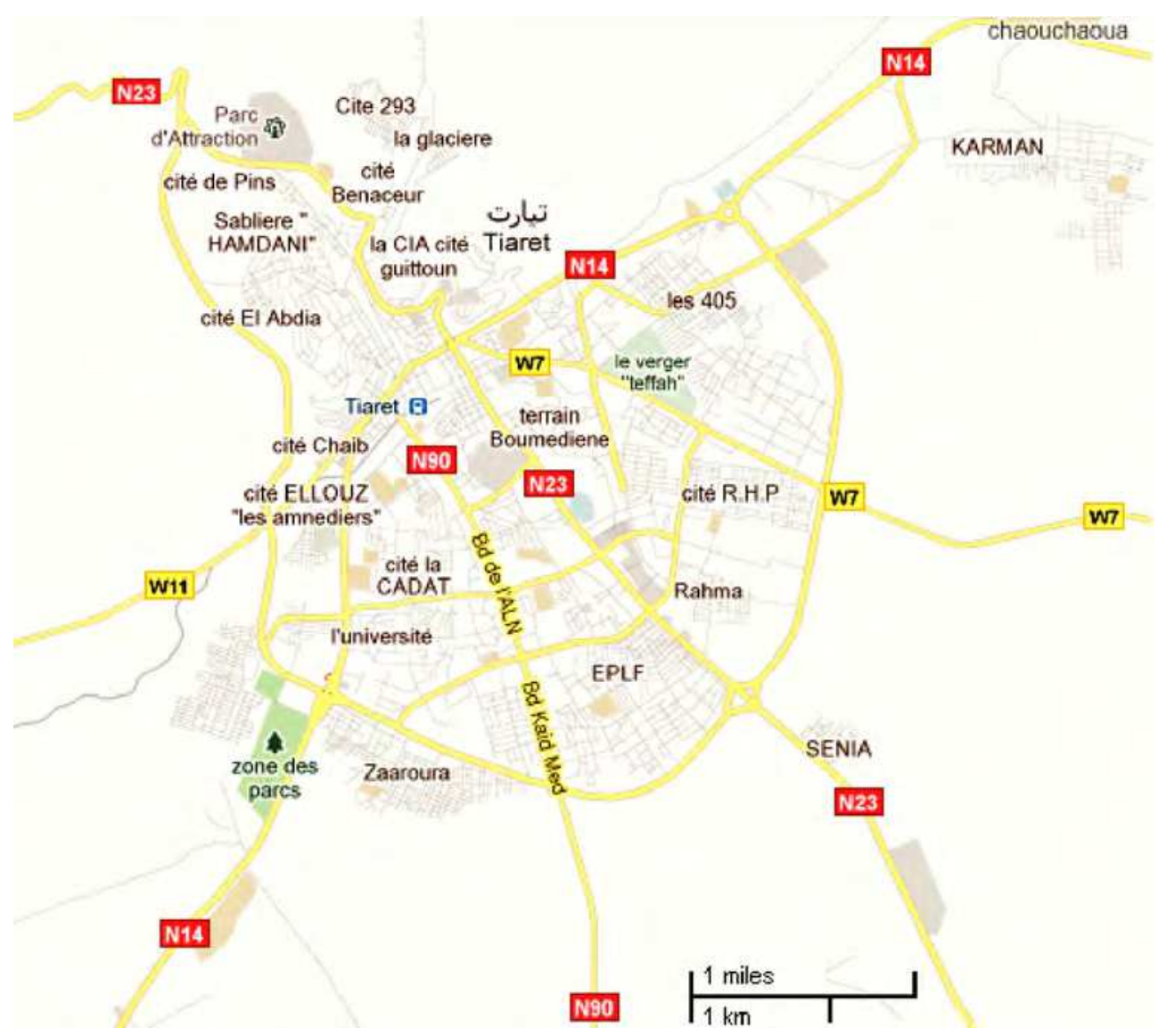

Fig. 1. Study site.

The samples were taken after a period without rain, one month after the release of young leaves and needles (Hébrard-Labit et al, 2004). Harvested leaves previously measured have been conserved in plastic bags with a rubber band, to ensure the conservation of water evaporation.

\subsubsection{Samples treatment}

In the laboratory, shoots were harvested without previous washing, were the subject of a series of transactions that are:

- Weighing: for the weight of the fresh material FM, about $200 \mathrm{mg}$ of fresh shoots were harvested in each tree,

- Drying: the usual method is drying in an oven at $40 \pm 2{ }^{\circ} \mathrm{C}$ then dried leaves were weighed for the dry matter weight DM determination, 
- Grinding: this step is highly critical as it can be a source of contamination or losses. For the leaves, in this case, the coffee grinder that allows incorporating the wad to the powder plant is used. The materials of the grinder are made of titanium, steel guaranteed without heavy metal.

- Mineralization and dissolved: the fine powder obtained is placed in an acid solution and oxidant $(0.5 \mathrm{ml}$ of nitric acid) and then heated in a water bath for $24 \mathrm{~h}$, until the destruction of organic matter. Tubes that have been supplemented by boiling $10 \mathrm{ml}$ of distilled water. This method allows the determination of all trace minerals.

The quantification of metals in solution is carried out by atomic absorption spectrometry with electrothermal atomization mode (Spectrometer Perkin Elmer 100).

\subsection{Results and discussion}

\subsubsection{Comparison Fresh Matter/Dry Matter (FM/DM) ratio between control and polluted sites}

Many authors have demonstrated that metals induce, from a certain threshold, biochemical and physiological dysfunctions. The macroscopic effects of aerial parts appear for high concentrations. It is essentially a reduction in leaf length and biomass produced (Vazquez et al, 1992; Brown et al, 1994; Ouzounidou et al, 1995; Ouzounidou et al, 1997).

In contact with a plant, the pollutant can be deposited on the surface then causing an alteration in the activities of photosynthesis and respiration (dust deposits), or into the tissues of the plant, causing tissues lesion, metabolic dysfunctions and disorders of the regulatory mechanisms.

The damages observed, mainly external, accompanied by a decrease in crop production and consequently a certain decline in agricultural and forestry yields (Belouahem, 1993). The excess of lead, for example, in plants induced physiological and biochemical injuries decreasing photosynthesis and transpiration thus leading to growth retardation (Bazzaz et al., 1974).

The report on fresh/dry matter is one of the indicators of air quality in a given urban areas. When the air is healthy, the plant development is normal, however, if the air is contaminated, the plant development is disturbed, resulting in manifestations of chlorosis, necrosis, etc ... at the expense of the fresh matter. The ratio FM/DM of a polluted area is lower than that recorded in an unpolluted area.

It should also be noted that very often this pollution is not the major cause. Indeed, in the city, trees are subjected to many other stressors that affect their health: mechanical stress, climate stress: high temperature, wind, light stress and poor soil quality (dry, mineral poverty, uneven texture, canalization, etc). It is recognized that the poor health of trees in town usually comes from poor soil quality (Domergue-Abak, 1981; Peulon, 1988).

Data analysis (Table 2) allows, at first, to see that the ratio FM/DM is higher in the control site compared to contaminated sites by pollutants issues from road traffic $(7.52 \pm 0.004$ and $3.85 \pm 0.004$ respectively in the plane tree and the cypress). The lower FM/DM ratio is found in the leaves of plane tree, these leaves seem to assess the air quality in the city better than Cypress (see Table 2). 


\begin{tabular}{|l|c|c|c|c|c|c|c|c|}
\hline Site & Species & Trees & Measures/Tree & N & Mean & Min & Max & Stand.deviation \\
\hline \multirow{2}{*}{ S1 } & Plane & 3 & 2 & 6 & 3.11 & 3,10 & 3,12 & 0.007 \\
\cline { 2 - 9 } & Cypress & 3 & 2 & 6 & 4,42 & 4,40 & 4,44 & 0,110 \\
\hline \multirow{2}{*}{ S2 } & Plane & 3 & 2 & 6 & 2,68 & 2,68 & 2,69 & 0,002 \\
\cline { 2 - 9 } & Cypress & 3 & 2 & 6 & 2,58 & 2,58 & 2,59 & 0,004 \\
\hline \multirow{2}{*}{ S3 } & Plane & 3 & 2 & 6 & 2,94 & 2,94 & 2,96 & 0,007 \\
\cline { 2 - 9 } & Cypress & 3 & 2 & 6 & 3,91 & 3,91 & 3,92 & 0,003 \\
\hline \multirow{2}{*}{ S4 } & Plane & 3 & 2 & 6 & 2,72 & 2,72 & 2,729 & 0,002 \\
\cline { 2 - 8 } & Cypress & 3 & 2 & 6 & 2,65 & 2,65 & 2,659 & 0,001 \\
\hline \multirow{2}{*}{ Control } & Plane & 3 & 2 & 6 & 7,52 & 7,52 & 7,532 & 0,004 \\
\cline { 2 - 8 } & Cypress & 3 & 2 & 6 & 3,85 & 3,85 & 3,865 & 0,004 \\
\hline
\end{tabular}

Table 2. Comparison FM/DM ratio of polluted sites to the control site.

In towns and neighborhoods of trunk road traffic, tree leaves constitute a very good collectors of dust and heavy metals. This deposition causes a high decrease in photosynthetic activity of the tree, growth reduction, leaf necrosis and leaf discoloration. The result is a subsequent reduction of the weight of the fresh matter of harvested leaves, and consequently, a low ratio FM/DM.

Bhatti et al. (1988) and Joumard et al. (1995) showed that the growth of new shoots in the Norway spruce was reduced by $25 \%$ along the highway compared to control trees, which results in a decrease in the surface and the length of the sheet.

These results are almost seen in Figure 2, showing a significant negative correlation between $\mathrm{Pb}\left(\mathrm{r}=-0.29^{*}\right)$ and the ratio FM/DM and a highly significant negative correlation for $\mathrm{Zn}(\mathrm{r}=$ $\left.-0.36^{* *}\right)$, however, it has no meaning for $\mathrm{Cu}$ metal. Thus, when the ratio is low, it means that the weight of the fresh matter is low and levels of trace elements are high. The effects of pollutants related to road traffic in urban areas on plants growth and development should be to induce alterations in their physiology.

\subsubsection{Trace metals contents $(\mathrm{Pb}, \mathrm{Zn}, \mathrm{Cu})$ in different sampling sites}

Different concentrations accumulated by the plane and the cypress tree are shown in Figure 3 , in the form of box plots with histogram, from which we find that:

In the leaves of plane, the levels of lead, zinc and copper (average values for all sites, respectively: $0.28 \pm 0.05,3.97 \pm 0.58$ and $0.11 \pm 0092 \mu \mathrm{g} / \mathrm{g}$ ) are higher about $50 \%$, compared to trees growing in the control site (recorded values, respectively: $0.13 \pm 0.001,1.31 \pm 0.005$ and $0.01 \pm 0.00 \mu \mathrm{g} / \mathrm{g}$ ). Atmospheric deposition of road traffic are, in this case, the main sources of $\mathrm{Pb}$ and $\mathrm{Zn}$, knowing that the concentration of metal in the soil solution is extremely small compared to the content of the fixed phase.

Soil lead is not very mobile and not available to plants. It accumulates mainly in the roots which, in some cases, it precipitates as phosphate (ADEME, 2005). Zinc also has a predominantly anthropogenic origin. As an illustration, $96 \%$ of zinc air emissions are anthropogenic (Colandini, 1997). It comes mainly from the leaching of roofing, corrosion of pipes and galvanized materials as well as tire wear (Chocat, 1997). Its presence is permanent and generalized to all urban sites, and does not present seasonality. 

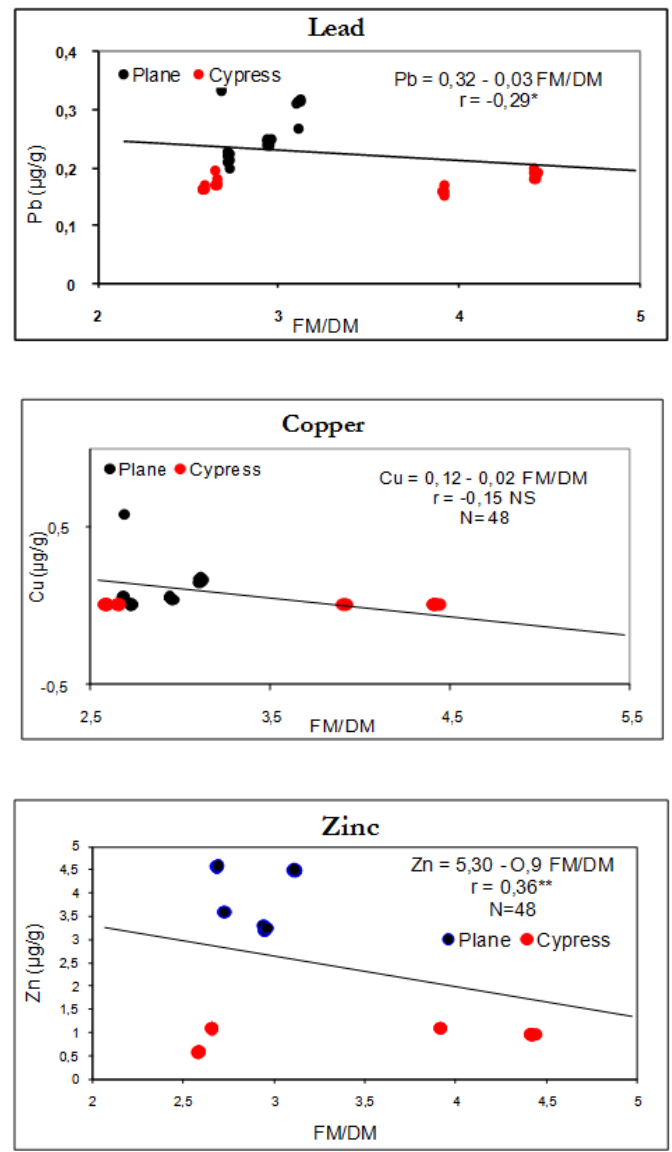

*: Significant correlation at $5 \%$

**: Significant correlation at $1 \%$

NS: No significant correlation

Fig. 2. Correlation: ratio FM/DM - trace metals $(\mathrm{Pb}, \mathrm{Zn}, \mathrm{Cu})$ contents.

In the case of cypress leaves, concentrations of lead and zinc recorded in the city were moderately low compared with plane tree leaves (average values for all sites, respectively: $0.17 \pm 0013$ and $0.93 \pm 0.20 \mu \mathrm{g} / \mathrm{g}$ compared to the control site in the order of $0.10 \pm 0.005$ and $0.4 \pm 0.00 \mu \mathrm{g} / \mathrm{g}$ ). This significant difference in concentrations of metals accumulated in plane and cypress trees is partly due to the leaf surfaces collector of particles (mainly in the epicuticular waxes) on a hand and to the difference between particles of lead and zinc on the other hand. Garrec et al. (2002) showed that gaseous and particular pollutants accumulated mainly on leaf surfaces following the highly lipophilic properties of cuticular waxes, with the key a bit of disturbing effects on plants.

Note that high concentrations for the three metals measured were noted in sites S1 and S2, the characteristics of mountain areas affected by a relatively steep slope and very important 
road traffic, the slope causes the engine to develop more power and reject more pollutants. The slope therefore causes a significant increase of emissions (Madany et al, 1990).

Moreover, for all sites measured, equal concentrations of copper were observed $(0.01 \pm 0.00$ $\mu \mathrm{g} / \mathrm{g}$ ) between the urban and the control cypress, where it can be assumed that copper accumulation from road traffic is absent in the leaves of this species.
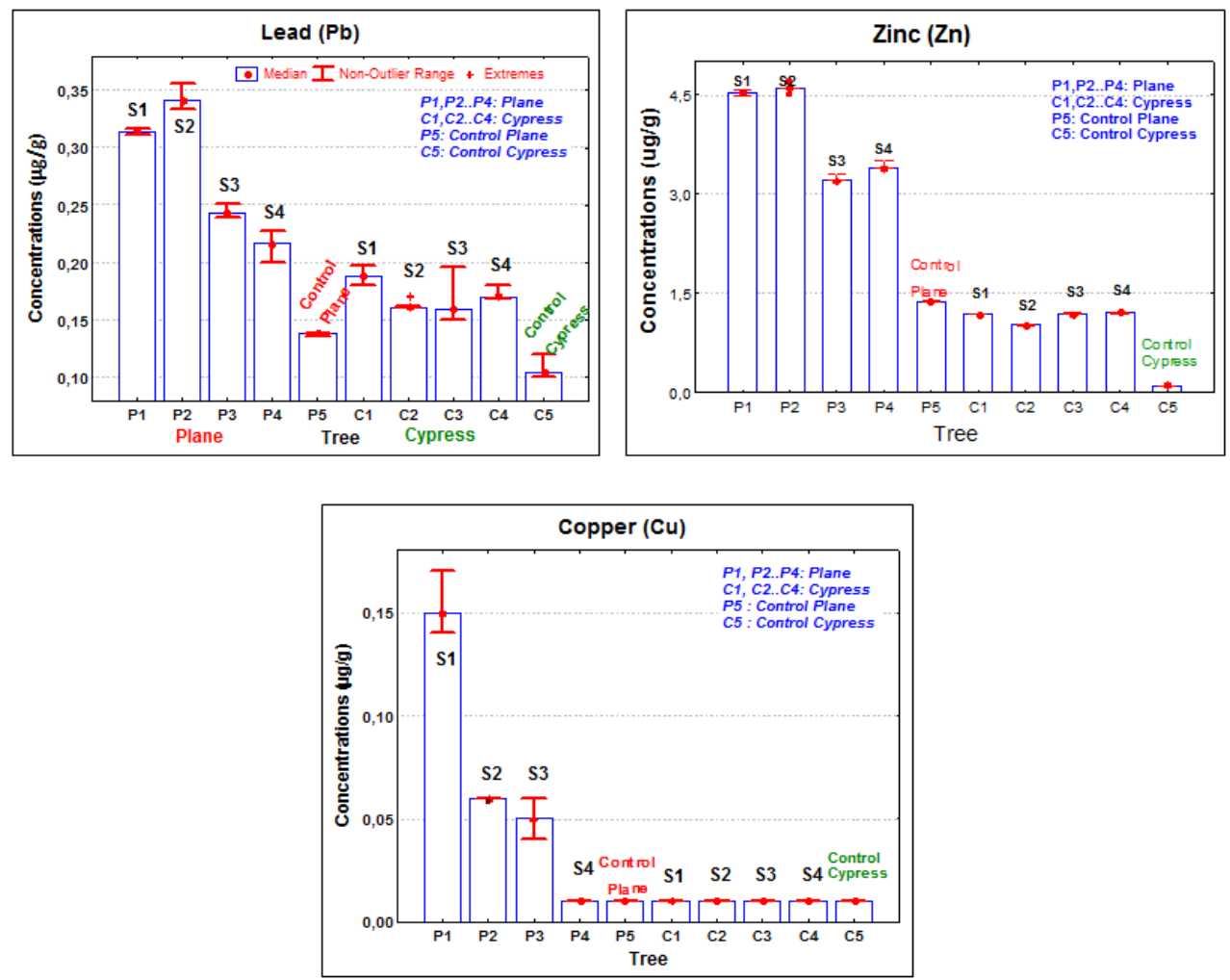

Fig. 3. Comparison of trace metals contents $(\mathrm{Pb}, \mathrm{Zn}, \mathrm{Cu})$ between control and polluted sites.

\subsubsection{Relationship between trace metals contents $(\mathrm{Pb}, \mathrm{Zn}, \mathrm{Cu})$ and urban sites}

In this section, we conducted a correspondence analysis by addressing the relationships between variables: concentrations of trace metals $(\mathrm{Pb}, \mathrm{Zn}, \mathrm{Cu})$ and contaminated sites by these elements. First of all, we have a table with one entry consisting of data from four sites (two measurements per tree, six measurements per site), then the variables said lines (four sites) were linked to the values concentrations of trace metals called variable columns with a cross table.

For this analysis, the percentages of inertia explained by each axis, were considered, including the relative differences have to know the number of axes that can be interpreted. The results of this Factorial Analysis of Correspondence are shown in Figure 4. 


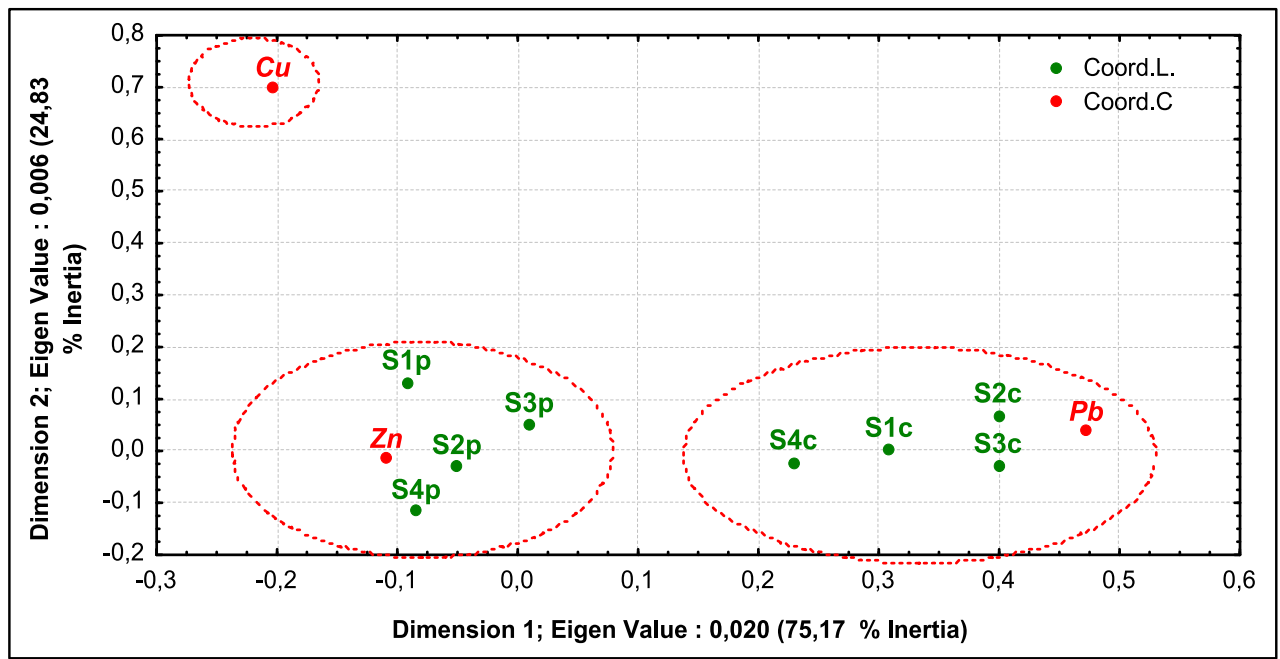

S1p...S4p : Downtown sites (bioaccumulative species: plane-tree) S1c...S4c : Downtown sites (bioaccumulative species Cypress-tree)

Fig. 4. Results of Factorial Analysis of Correspondence between traces metals content and polluted sites.

Two axes may be interpreted to show that about $75 \%$ and $25 \%$ of the dispersion of the cloud variables made respectively in the plane of the two axes:

Axis No. 1 (75.17\% of the total inertia of the cloud):

Variables that contribute substantially to the inertia of this axis are:

\section{The negative side}

- Variable lines: the four urban sites S1p, S2p, S3p and S4p where the plane tree was found to be bio-accumulative essence,

- Variables-columns: one modality was found: zinc (Zn). This association between the four urban sites and accumulation of zinc explains that the plane tree leaves that are smooth and wide accumulate more zinc than lead, despite the high levels of lead stored in these sites.

In this context and in hyper-accumulator plants, accumulation is observed in epidermal cells for zinc in Arabidopsis halleri (Dahmani-Muller, 2000) and for nickel in Alyssum lesbiacum and Thlaspi goesingsense (Kupper et al., 2001). This distribution has also been demonstrated for zinc in barley when the exposure level of the plant increases (Brown et al, 1994).

\section{The positive side}

Examination of the axis on a positive side to define the association of the four urban sites S1c, S2c, and S3c S4c using cypress with lead $(\mathrm{Pb})$. So the cypress has a tendency to accumulate more lead than zinc.

Several factors may be involved in the susceptibility of leaves to pollutants such us the particles emitted by road traffic which are better captured by rough surfaces, and the 
presence of a hair growth promoting their retention by the smooth epidermis. It should be noted that for the same site and same exposure to traffic pollution, leaves of Terminalia catapa that are rough and large accumulated about two fold more lead than Nerium oleander leaves that are smooth and wide (Vazquez et al, 1992).

Axis No. 2 (24.83\% of the total inertia of the cloud)

In this axis, a single modality was found: copper $(\mathrm{Cu})$. It was confirmed from Figure 4 of subsection 3.2 that copper is weakly accumulated by the plane, for against; it does not accumulate at all in the leaves of cypress. These results confirm the observations of the AFC in this axis. Note also that copper is a trace element essential to the physiological functioning of the plant, in this case, it is likely that low levels of copper were used by the trees.

Results show that the ratio fresh weight/dry weight that is an indicator of air quality in the area of investigation is negatively correlated with the concentration of trace elements. It is extremely low in the contaminated sites, reflecting the effect of pollutants originated from the traffic on the vigor and the physiological activity of trees nearby. These trace metals accumulated in leaf surfaces following the micro-relief created by cuticular waxes, or enters the leaf through stomata.

Furthermore, we found that the plane tree leaves accumulate more zinc than lead. Nevertheless, among the cypress, the degree of accumulation of lead is greater than that of zinc, furthermore, very low concentrations or absent of copper were observed in both species. In addition, these results show the interest of the use of leaves of woody plants as bioindicators of air contamination. Thus, urban trees can form networks of plant bioindicator of air pollution.

\section{Case II Mapping of atmospheric pollution by heavy metals originated from road traffic using a transplanted bioaccumulative lichen Xanthoria parietina in the city of Tiaret (Algeria)}

The monitoring of trace metals pollution obeys at specific constraints that require the deployment of sophisticated and expensive techniques. These constraints have led many countries to promote the use of living organisms in which monitored contaminants are assayed. Thus, since the early 1990s, thirty of European countries have established a network of biomonitoring of metal atmospheric deposition using plants, lichens, mosses, etc... (Leblond, 2004).

Lichens are organisms that are particularly well suited for the study of gaseous and particulate pollutants. They owe this effectiveness due to their anatomical particularities (vegetative structure in the form of thallus leading to a high ratio surface/volume, absence of waxy cuticle, stomata and conducting vessels, presence of a cortex often rich of mucilage and pore) and their physiological characteristics. They will therefore be subject to the effects of pollutants in both dry and wet deposition (Garrec and Van Haluwyn, 2002).

Deruelle (1984) transplanted lichens at distances ranged between 5 and $10 \mathrm{~m}$ from the road. After exposure more or less prolonged, transplants are returned to their native communities under unpolluted atmosphere and assays are conducted at regular intervals in order to test decreases of lead concentration. 
Semadi and Deruelle (1993) indicated two methods of lichen transplantation. The first is to graft a disk supporting bark lichen on a tree of the same species, if possible, or on a board. The second is to expose branches covered with lichen thalli. The authors affirm that the latest method was used for Hypogymnia physodes and Ramalina duriarei. The latter method was chosen because it is easier. Indeed, it is not necessary to conduct sampling to the board. Lichens were transplanted six months to a distance of $5 \mathrm{~m}$ and $10 \mathrm{~m}$ of roads characterized by heavy traffic along predefined transects. Lead assays are performed each month on all graft at every site. Assays were performed using a method similar to that employed by (Deruelle, 1981).

\subsection{Materials and methods}

\subsubsection{Transplantation of the lichen Xanthoria pariteina}

The experimental protocol used in this study is to transplant the lichen Xanthoria pariteina in the city, this lichen species is abundant in the region of Tiaret and has been the subject of numerous scientific studies (excellent accumulator of heavy metals). This technique developed by (Brodo, 1961) based on transplantation into a site to evaluate, lichens originating from a reference site, exempt of contamination. Transplanted samples were collected from uncontaminated areas (the cedar forest of the national park of Theniet al Had at $120 \mathrm{~km}$ Northern of Tiaret) which ecological conditions are similar as possible. Lichens controls, far from any source of contamination of air pollution, have been used to serve as references when comparing with contaminated lichens.

Transplantation was performed on selected stations in the city, whose location is determined from a mesh of the sampled area (Figure 3). The study sites are located either at the intersection of the mesh, in the middle of each mesh (mesh size of the territory of $0.5 \mathrm{~km}$ $x 0.5 \mathrm{~km}$ ) (Garrec and Van Haluwyn, 2002). On total, 48 lichen samples were transplanted in different sites in the city, and each lichen sample is set in a tree trunk at $1.30 \mathrm{~m}$ high (Maatoug, 2010). The duration of transplantation was determined by one month (from April 21 to May 22, 2008).

\subsubsection{Samples collect}

The material is taken to limit contamination: neither losses nor pollution, avoiding the use of tools or containers that may contaminate the sample (tool steel or stainless steel containers whose walls contain pigments based on trace elements, such as PVC). The geographical coordinates $(x, y)$ of each transplant were recorded using a GPS.

The lichen samples are collected, registered and transported in dry paper on the day of harvest.

\subsubsection{Sample processing}

Most often, methods of preparation and determination of metals in soil are the same for plant leaves, lichens and fungi (Alfani and Baldantoni, 2000). The most commonly used is the dosage in the thalli of lichen collected from the study site. Lichen samples were taken on the same day for each study area, facing the highway and at $1.3 \mathrm{~m}$ above the ground. The assay was performed after dehydration at least 72 hours at $105^{\circ} \mathrm{C}$, weighing and cleaning 
with boiling hydrogen peroxide to mineralize the lichen. The assay is performed in a solution of $\mathrm{HCl}$ decinormal (Deruelle, 1981).

In the laboratory, harvested thalli without prior washing have been subject to a series of transactions that are:

- Dehydration of thalli: the usual method is dehydration in an oven at $105 \pm 2{ }^{\circ} \mathrm{C}$ during 72 hours. Dried thalli were weighed for dry matter DM determination, about 0.2 to $0.3 \mathrm{~g}$.

- Grinding: This step is highly critical because it can be a source of contamination or losses. For lichens, the grinder used is an agate mortar. Grinder materials are made of titanium, steel guaranteed free of heavy metals. The resulting powder is calcinated in an oven whose temperature is gradually increased up to $500^{\circ} \mathrm{C}$, using quartz capsules.

- Mineralization and dissolved: the fine powder obtained after calcination, is placed in an acidic and oxidizing solution $(0.5 \mathrm{ml}$ mixture of nitric acid $\mathrm{HNO}$, hydrofluoric acid $\mathrm{HF}$ and perchloric acid $\mathrm{ClHO} 4$ ) and then heated in a water bath for $24 \mathrm{~h}$ until the complete destruction of organic matter. Tubes that have been boiling are supplemented by $10 \mathrm{ml}$ of distilled water. This method allows the determination of all trace minerals.

The determination of lead and Zinc is performed by atomic absorption spectrometry with electrothermal atomization mode (Perkin Elmer spectrometer 100).

\subsection{Results and discussion}

The determination of lead and Zinc was performed on 46 samples. Initially, we sought to consolidate the concentrations that are most like them, to achieve this objective; we submitted data to an automatic classification (hierarchical cluster where the distance measurements are those of the Euclidean distances).

The automatic classification allows identifying three distinguishable classes of pollution by lead and four polluted classes by zinc. The results of this classification are shown in Fig. 5 and 6 :

\subsubsection{Lead}

The concentrations of lead accumulated by the lichen Xanthoria parietina are presented in Table 1, as classes of pollution defined by automatic classification method.

\begin{tabular}{|c|c|c|c|c|c|c|c|c|}
\hline & $\mathbf{N}$ & Mean & Median & Min & Max & $\begin{array}{c}\text { 1st }^{\text {st }} \\
\text { Quartile }\end{array}$ & $\begin{array}{c}3^{\text {rd }} \\
\text { Quartile }\end{array}$ & $\begin{array}{c}\text { Stand. } \\
\text { Dev }\end{array}$ \\
\hline Class 1 & 5 & 237,60 & 238,00 & 229,00 & 248,00 & 234,00 & 239,00 & 7,02 \\
\hline Class 2 & 4 & 194,00 & 192,00 & 184,00 & 208,00 & 185,00 & 203,00 & 11,19 \\
\hline Class 3 & 37 & 76,31 & 76,90 & 43,80 & 119,00 & 61,50 & 89,60 & 19,02 \\
\hline Control & 4 & 28,35 & 28,20 & 27,80 & 29,20 & 28,00 & 28,70 & 0,59 \\
\hline
\end{tabular}

Table 3. Descriptive statistics of different classes of lead pollution $(\mu \mathrm{g} / \mathrm{g})$ in the city of Tiaret (Maatoug, 2010). 
The reading of Table 3 shows that:

- $\quad$ Lead levels (mean values for all classes, ranges from $76.31 \pm 19.02 \mu \mathrm{g} / \mathrm{g}$, with extreme values 43.80 and $119.00 \mu \mathrm{g} / \mathrm{g}$, at $237.60 \pm 7.02 \mu \mathrm{g} / \mathrm{g}$ with extreme values 229.00 and 248 $\mu \mathrm{g} / \mathrm{g})$ are higher than the lichens control $(28.35 \pm 0.59 \mu \mathrm{g} / \mathrm{g}$ with extreme values 27.8 and $29.2 \mu \mathrm{g} / \mathrm{g}$ ). Semad and Deruelle (1993) show that the average lead content in thalli of Ramalina farinacea, transplanted and harvested in the region of Annaba (Algeria) at 5 $\mathrm{m}$ from the floor, is about $60 \mu \mathrm{g} / \mathrm{g}(\mu \mathrm{g} / \mathrm{g}$ ) (transplantation for 1 month). Our results indiquate that Xanthoria pareitina accumulates much more lead than Ramalina farinacea (Maatoug, 2010),

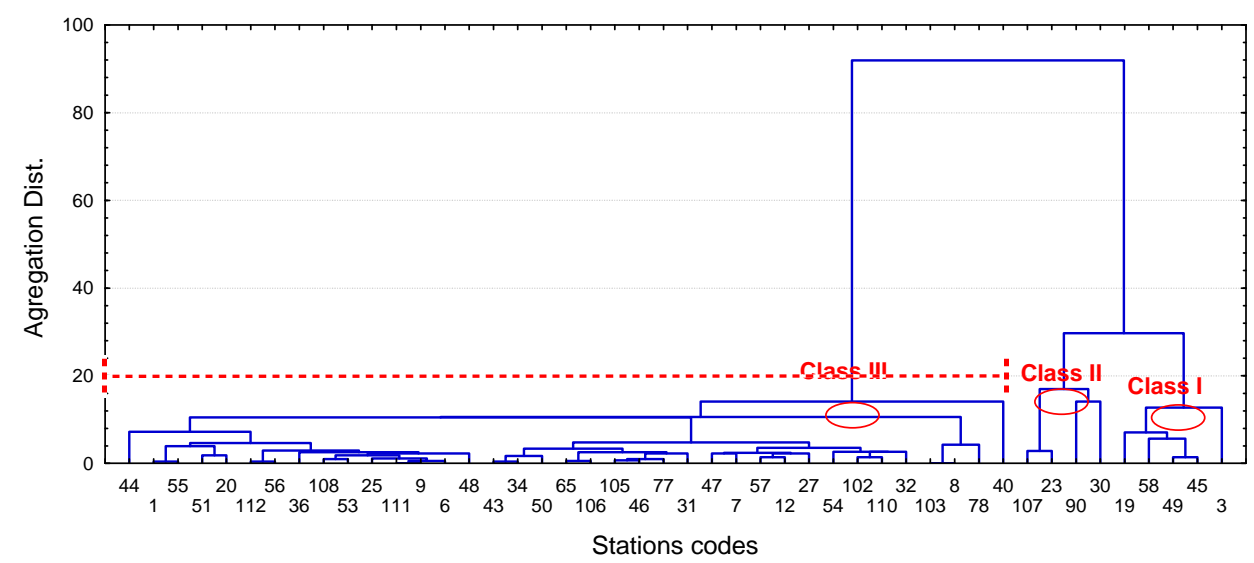

Fig. 5. Three lead polluted classes according to cluster analysis method.

- High concentrations of lead are registered in the class I, the maximum value can reach $248 \mu \mathrm{g} / \mathrm{g}$. This class, called hot class, brings together the most polluted sites assigned a very high traffic and steep slope where the frequency of braking and idling is extremely important (especially the north and center of the city). Maatoug (2007) found high concentrations of lead in central and north side of this city, by the use of cypress with leaves evergreen and plane with leaves of maple.

- Classes 2, regroups, in a regressive way, sites or emissions of lead relatively less important as sites of Class 1 ,

- Low concentrations were noted in class 3 around the value $76.31 \pm 2.19 \mu \mathrm{g} / \mathrm{g}$, but still elevated compared with control sites. We can also divide this class into 3 subclasses whose lead levels are varied from $49.80 \pm 4.78$ at $60 \pm 5.30 \mu \mathrm{g} / \mathrm{g}$ for the 1 st subclass, from $60 \pm 5.30$ to $90 \pm 2.80 \mu \mathrm{g} / \mathrm{g}$ in the 2 nd subclass and from $90 \pm 2.80$ at $119 \pm 5.20$ for the 3rd subclass. It is assumed that this class, including subclasses, includes the remaining stations (37 observations) which are located in a relatively low road area (the south side of town) as the sites of classes 1 and 2. It is important to note that these sites are fairly open in urban areas and have relative protection, movement of air masses influencing the dispersal of pollutants (Maatoug, 2010) 


\subsubsection{Zinc}

Automatic classification defines four classes of pollution by zinc indicated by the lichen Xanthoria parietina. Results are shown in the following table 4.

\begin{tabular}{|c|c|c|c|c|c|c|c|c|}
\hline & $\mathbf{N}$ & Mean & Median & Min & Max & $\begin{array}{c}1^{\text {st }} \\
\text { Quartile }\end{array}$ & $\begin{array}{c}3^{\text {rd }} \\
\text { Quartile }\end{array}$ & $\begin{array}{c}\text { Stand. } \\
\text { Dev }\end{array}$ \\
\hline Class 1 & 6 & 1160,72 & 1013 & 882 & 1665 & 963,85 & 1311 & 272,28 \\
\hline Class 2 & 6 & 693,362 & 695 & 621,5 & 740 & 665,2 & 732,5 & 42,24 \\
\hline Class 3 & 11 & 338,42 & 306,5 & 262,2 & 515 & 293 & 360 & 77,83 \\
\hline Class 4 & 21 & 101,4 & 97,7 & 10,3 & 190 & 63,9 & 144,6 & 55,29 \\
\hline Control & 4 & 40.50 & 41.00 & 30.00 & 50.00 & 33.50 & 47.50 & 8.81 \\
\hline
\end{tabular}

Table 4. Descriptive statistics of different classes of zinc pollution $(\mu \mathrm{g} / \mathrm{g})$ in the city of Tiaret.

By the same way as lead, Zinc content (average values for all classes, range from $101.4 \pm 55.29$, with extreme values of 10.3 and $190 \mu \mathrm{g} / \mathrm{g}$, to $1160.72 \pm 272.28 \mu \mathrm{g} / \mathrm{g}$ with extreme values of 882 and $1665 \mu \mathrm{g} / \mathrm{g}$ ) is higher in sampling sites than those of the control $(40.50 \pm 8.81 \mu \mathrm{g} / \mathrm{g}$ with extreme values 30.00 and $50.00 \mu \mathrm{g} / \mathrm{g})$. Recorded values are also higher when comparing with those found in lichens by Van Haluwyn and Cuny (1997) between 30 and $50 \mu \mathrm{g} / \mathrm{g}$.

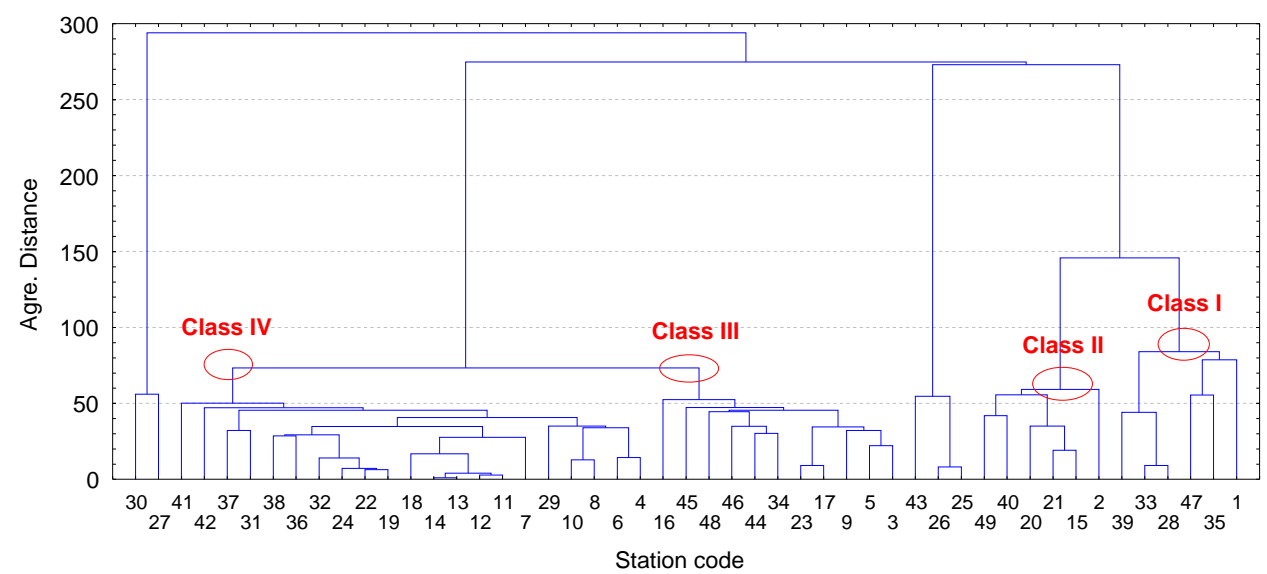

Fig. 6. Four Zinc polluted classes according to cluster analysis method.

High concentrations of zinc are recorded in Class I with a maximum value of $1665 \mu \mathrm{g} / \mathrm{g}$. This class hot regroups together the most polluted sites by high road traffic and situated in steep slope where the frequency of braking and tire wear is important. 
Class 2 includes, in regressive way, sites supporting zinc emissions less than the first class. The concentrations of zinc found in Class 3 range around a value of $338.42 \pm 77.83 \mu \mathrm{g} / \mathrm{g}$ but still high compared to the sites of class 4 which includes the sites with low traffic levels. It is important to note that these sites are quite open in urban areas, is what promoted the dispersion of pollutants.

\subsubsection{Establishment of map pollution}

Mapping of spatial lead and zinc pollution in the city of Tiaret was produced by the automatic method, interpolation/extrapolation, of data collected in situ of lead pollution knowing the extent of pollutants concentration in some points using the software MapInfo ${ }^{\odot}$ and Vertical mapper ${ }^{\mathrm{TM}}$ ) (Garrec and Van Haluwyn, 2002). The geographical coordinates of each observation, were obtained by a GPS. We finally got a file of 46 readings with the coordinates $(x, y, z), z$ is the concentration of lead in the site. The details of this mapping are illustrated in Figure 5, taking into account the results of automatic classification.

\subsubsection{Map reading}

Looking at the map of Figure 7a, therefore we can define three classes of lead pollution, from an average of $76.31 \mu \mathrm{g} / \mathrm{g}$ to $237.60 \mu \mathrm{g} / \mathrm{g}$. The highest concentrations of lead are found in Class 1 , indicated by a red color. In this class, the most sites are located in the main axe NorthCenter-South of the city. These observations have led to distinguish the deteriorating of air

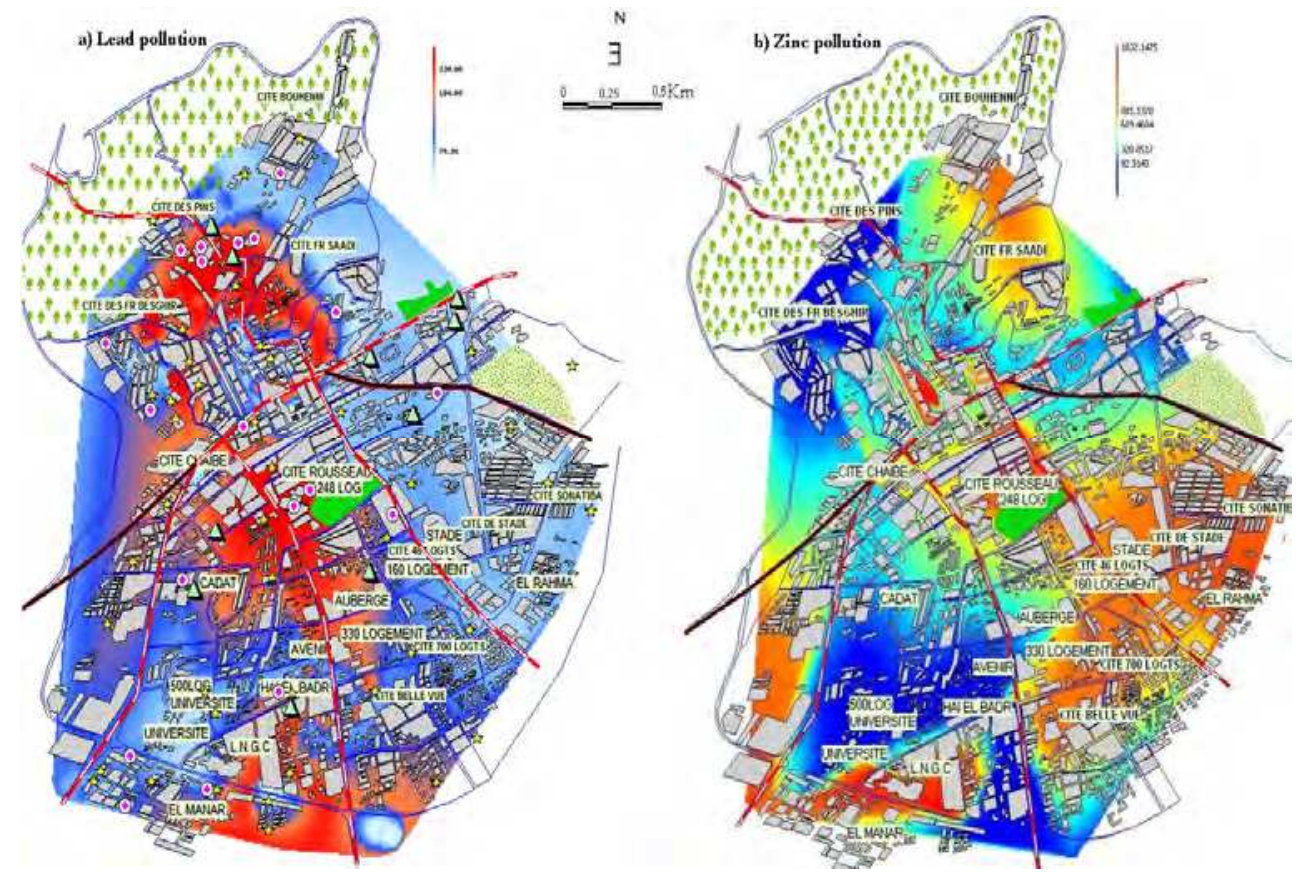

Fig. 7. Map of atmospheric pollution by lead and zinc from road traffic in Tiaret city. 
quality in these sites and that atmospheric deposition of road traffic are, in this case, the main sources of lead pollution, knowing that the ground contribution of this metal are nil. However, sites of this class, called hotspots, are mountainous areas affected by a relatively steep slope and a very important traffic, slope forces the engine to develop more power and emit more pollutants, so it causes a significant increase in emissions (Madany et al., 1990).

High levels have also been observed in class 2, these results suggest, in a first approach, the environmental conditions, including pollution of lead, have an important responsibility on the poor air quality in these cities. It is important to note that a significant number of schools are located in these hotspots that constitute a danger on the students health.

In Class 3, low values were observed, these sites are fairly open, promoting the dispersion of atmospheric deposition that are transported by wind.

Zinc is a very ubiquitous. It is used in a very large number of materials in the form of oxide, sulfate, chloride or organic. It is usually emitted into the atmosphere in the form of small particles from road traffic and various industries. Our results concerning polluted zinc repartition indicate the presence of four classes according to the automatic classification method;

As shown in Figure 7b, we can define four classes of zinc pollution, from an average of 101.4 $\mu \mathrm{g} / \mathrm{g}$ to $1160.72 \mu \mathrm{g} / \mathrm{g}$. The highest concentrations are grouped in class 01 , represented also by the red color, were observed at the southern part corresponds to a high movement especially in peak hours because it constitutes a principal way in the city.

There are also hot spots in the north where we can explain the accumulation of pollutants by the relief nature more than the rate of traffics because of the steep slope which reduces the dispersion of pollutants and thus promotes their accumulation in the medium, and therefore, by lichens.

Sites of the Class 2 support the same road traffics than the first except that these sites are open environments that lead the wind to disperse these pollutants.

For Class 3, low values are recorded corresponding to a temporal and intermittent circulation in these sites during the day.

Finally the Class 4 includes sites of the lowest values of zinc concentrations, these stations are open and wide characterized by very low traffic movements.

\section{Case III Comparison between levels of lead accumulated by trees to those accumulated by the lichen Xanthoria parietina transplanted into the city of Tiaret}

In towns and neighborhoods of trunk road traffic, plants leaves are also collectors of dust and heavy metals.

In this context, a quantification of lead and zinc deposition originated from road traffic has been made in the same city, from the leaves of two types of trees growing in the center of the city. There are six trees Platanus acerofolia.Willd and six trees Cupressus sempervirens.L divided into two sites S1 and S2 (Fig. 5). For each tree, fifty leaves are collected, they were the subject of lead and zinc determination (Maatoug, 2007). 
On the same trees (the same sites S1 and S2), lichens Xanthoria pareitina were transplanted following the steps described in previous paragraph. Results of this comparison are illustrated in Figure 8.

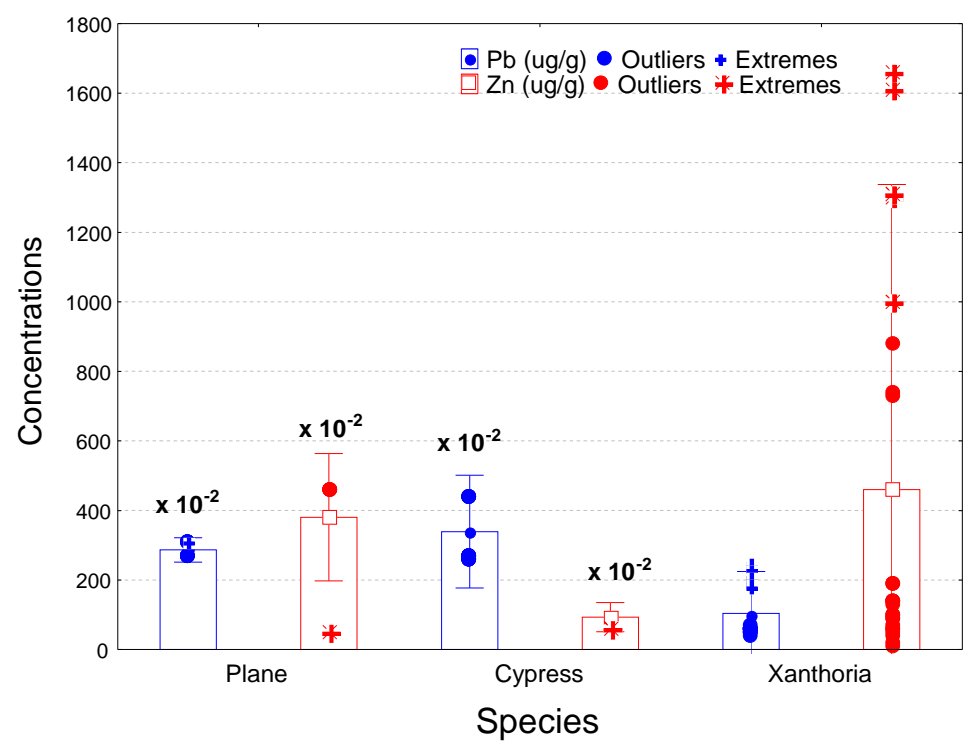

Fig. 8. Comparison between contents of lead and zinc accumulated by trees (Plane and Cypress) to those accumulated by the lichen Xanthoria in Tiaret City.

We notice very clearly that lead storage capacity of Xanthoria is very high compared to that of the trees, the values are $1.04 \pm 0.60 \mu \mathrm{g} / \mathrm{g}$ in Xanthoria against $2.86 \pm 0.17 \times 10^{-2} \mu \mathrm{g} / \mathrm{g}$ and $3.39 \pm 0.01 \times 10^{-2} \mu \mathrm{g} / \mathrm{g}$ respectively in the plane and cypress.

By the same way, the Xanthoria accumulates $460.38 \pm 43.85 \mu \mathrm{g} / \mathrm{g}$ against $380.45 \pm 91.53 \times 10^{-2}$ $\mu \mathrm{g} / \mathrm{g}$ and $93.20 \pm 20.96 \times 10^{-2} \mu \mathrm{g} / \mathrm{g}$ respectively in plane and cypress leaves (Maatoug, 2010).

Lichens absorb indiscriminately by their pseudocyphelles all the nutrients as toxic substances. Absorption capacity of metals by lichens is directly related to their morphological and anatomical structures. Lichens accumulate more metals when their surfaces increase (Garty et al., 1996).

Sharing some biological traits (Asta et al., 2003), lichens have a relatively quick response to the deteriorating of air quality and are extremely sensitive to other types of environmental changes such as climate change and eutrophication (Galun, 1988), (Garrec and Van Haluwyn, 2002).

In trees, the emissions of lead and zinc originated from road traffic are mainly in the form of fine particles that are then collected by leaves surfaces. It is an assimilation of external metal pollutants. The significant difference in concentrations of lead and zinc accumulated between the plane and cypress is certainly due to the nature of leaves surfaces (mainly on 
epicuticular waxes) of each tree, the sycamore leaves, which are smooth and wide, accumulate substantially lead better than the cypress leaves.

Generally, optimal use of plants as means of investigation of air pollution concerns cases where the route of contamination by the soil is either nil, negligible or known. The transfer of a trace element from the soil to a harvest organ depends on both parameters related to soil and plant-specific factors. It results in some sort of meeting between ground supply and plants demand that are not completely independent. Therefore, the plants most used for these studies are mosses and lichens through, inter alia, their lack of root system.

\section{Conclusion}

Our study constitutes an attempt to evaluate the air quality in semiarid region, Tiaret city, from Algeria. The first aim of this work (case I) was to assess the most frequent atmospheric heavy metal, especially $(\mathrm{Pb}, \mathrm{Zn}, \mathrm{Cu})$, accumulated in leaves of two urban plant species, plane and cypress, in the context of their usefulness in urban environment as bioindicator or in phytoremediation. Results show that the ratio fresh weight/dry weight (FM/DM) of trees leaves, which is an indicator of air quality in the area of investigation, is negatively correlated with the concentration of trace elements. It is extremely low in the contaminated sites, reflecting the effect of urban pollutants on trees vigor and their physiological activity. Furthermore, we found that the plane tree leaves accumulate more zinc than lead against very low concentrations of copper. Nevertheless, among the cypress, the degree of accumulation of lead is greater than that of zinc, furthermore, very low concentrations or absent of copper were observed in both species. In addition, these results show the interest of the use of leaves of woody plants as bioindicators of air contamination and the impact of pollution on urban plants.

In order to identify the main source of lead and zinc accumulation in trees leaves then, in the intend of estimate concentrations of these pollutants and mapping their spatial repartition in the city (case II), lead and zinc was measured in 48-lichen Xanthoria parietina samples, transplanted for while into different sites located near major highways and in urban areas of Tiaret city. Automatic classification of data has shown three classes of lead-polluted sites and four classes of zinc-polluted sites. These results established that the degree of lead pollution including traffic and roads infrastructures is causing a major source of heavy metals in this city. All the observations of pollution have been mapped to reveal spatial pollution originated from road traffic and spot on the vulnerable sites. Hot points sites were locating on land with relatively steep slope and high traffic, so, this forces the vehicle to release a lot of smoke. Sites with low traffic are also open enough to promote the dispersion of atmospheric deposition. These maps could answer questions about the air pollution problem in Tiaret city. These biological methods contribute to a health risk assessment because they assist to identify areas potentially exposed to urban air pollution.

These maps could answer questions about the air pollution problem in Tiaret city. These biological methods contribute to a health risk assessment because they assist to identify areas potentially exposed to air pollution. Thus, urban trees can form networks of plant bioindicator of air pollution; the use appears to be particularly simple, economical and efficient method. The second part of the study has demonstrated the perfect suitability of lichens bioaccumulators for mapping different elementary deposits and location of sources 
of metals. Lichens and urban trees can form networks of plant bioindicators of air pollution, the use appears to be also very simple, flexible, economical and efficient to build good repartition in space and time maps of pollution. The identification of pollution within sensitive organisms can also detect the degradation of air quality before it severely affects the biota or humans.

Today, the use of motor vehicles has increased substantially in Algeria. However, in recent decades, urban and industrial developments have accelerated the use of motor vehicles. Unfortunately, at present, air pollution generated by traffic is taken into account only through its effects on human health. On the other hand, the reduction of pollutant emissions from road traffic demands renewal of Automobile Park and improvement of combustion engines using less pollutant fuels.

In the end, it appears that pollution related to road traffic has an impact on urban environment. Plant contamination comes mainly from the aerial parts, which are often the beginning of food chains with all the problems that may cause, particularly on human health. This study confirms the need to control the automobile park and to reduce emissions from road traffic by the renewal of the automobile park, improvements in the accuracy of regulating combustion engines and the use less pollutant fuels.

\section{References}

[1] ADEME,. Agence de l'Environnement et de la Maîtrise de l'Energie. Dérogations relatives à la réglementation sur l'épandage des boues de stations d'épuration. Comment formuler une demande pour les sols à teneurs naturelles élevées en éléments traces métalliques?. Guide technique. J. Béraud et A. Bispo (Coordinateurs). D. Baize, T. Sterckeman, A. Piquet, H. Ciesielski, J. Béraud et A. Bispo (2005). 120p

[2] Alfani, A. et Baldantoni. D. Temporal and spatial variation of C, N, S and trace element contents in the leaves of Quercus ilex within the urban area of Naples. Environ. Pollut. 2000 (109): 119-129.

[3] Asta, J., Erhardt, W., Ferreti, M., Fornassier, F., Kirschbaum, U., Nimis, P.L., Purvis, O.W., Pirintsos, S., Scheidegger, C., van Haluwyn, C., Wirth, V. (2003). European guideline for mapping lichen diversity as an indicator of environmental stress. 20p.

[4] Baize D., 1997. Teneurs totales en éléments traces métalliques dans les sols (France). INRA de France. Editions, Paris, 408p.

[5] Bazzaz, F.A., Rolfe, G.L., et Carlson, R.W., Effect of cadmium on photosynthesis and transpiration of excised leaves of corn and sunflower. Physiologia Plantarum, 1974 (32), 373-377.

[6] Belouahem D., Détection de la pollution atmosphérique fluorée d'origine industrielle à l'aide de certaines espèces végétales bioaccumulatrices dans les régions de Annaba et Taraf. Thèse de Magister. Institut National Agronomique INA (Algérie) 1993. $165 \mathrm{p}$.

[7] Bhatti G.H., Iqbal M.Z, 1988. Investigations into the effect of automobile exhausts on the phenology, periodicity and productivity of some roadside trees, Acta Societatis Botanicorum Poloniae, 57 (3). 395-399. 
[8] Brodo .I M. Transplant experiments with corticolous lichens using a new technique. Ecology 1961 (42): 838-841.

[9] Chocat, B.,. Eurydice. Encyclopédie de l'hydrologie urbaine et de l'assainissement. Paris : Tec et Doc Lavoisier. 1997, 1136 p.

[10] Colandini, V., Effets des structures réservoirs à revêtement poreux sur les eaux de ruissellement pluviales : qualité des eaux et devenir des métaux lourds. Thèse de doctorat. Pau. Université de Paut des pays de l'Adour (France) 1997, 161 p. + annexes

[11] Dahmani-Muller H., Phytoréhabilitation des sols pollués par des éléments métalliques : facteurs et mécanismes de prélèvement dans les sols et d'accumulation par les espèces métalliques. Thèse de l'Ecole Nationale de Génie rural, des eaux et des Forêts ENGREF (France) 2000, 151 p.

[12] Deletraz G., Géographie des risques environnementaux lies aux transports routiers en montagne. Incidences des émissions d'oxydes d'azote en vallées d'Aspe et de Biriatou (Pyrénées). Thèse de Doctorat en Géographie - Aménagement. Université de Pau et des pays de L'Adour. Institut de Recherche sur les Sociétés et l'Aménagement (France) 2002, 564 p.

[13] Delmas - Gadras C., Influence des conditions physico-chimiques sur la mobilité du plomb et du zinc dans un sol et un sédiment en domaine routier. Thèse de docteur de l'université de Pau et des Pays de l'Adour (France) 2000, 191 p.

[14] Deruelle .S. Effets de la pollution atmosphérique sur la végétation lichénique dans le bassin Parisien. Convention de recherche n 79-15, Ministère de l'Environnement et du Cadre de Vie 1981 : 91-112.

[15] Deruelle .S. L'utilisation des lichens pour la détection de la pollution par le plomb. Bull.Eco 1984 :1-6.

[16] Domergue-Abak. M.F., Etude de synthèse sur les causes de dépérissement de la végétation en milieu urbain, et notamment les arbres d'alignement. Rapport du Ministère de l’Urbanisme et du Logement (France) 1981, Nº 81/47142/00, 52p.

[17] Edwards N.T., 1986. Uptake, translocation and metabolism of anthracene in bush bean (Phaseolus vulgaris L.). Environ. Toxicol. Chem.. (5),659-65.

[18] Fernandez-cornudet,C., Devenir du $\mathrm{Zn}, \mathrm{Pb}$ et $\mathrm{Cd}$ issus de retombées atmosphériques dans les sols, à différentes échelles d'étude. Influence de l'usage des sols sur la distribution et la mobilité des métaux. Thèse de doctorat de l'INA-PG (France) 2006, 232p.

[19] Galun, M. Handbook of lichenology. Springer, 1988; 181p.

[20] Garrec j.p. et Van Haluwyn c., Biosurveillance végétale de la qualité de l'air. Concepts, méthodes et applications. Editions Tec et Doc Lavoisier, Paris (France) 2002,118 p.

[21] Garty, J., Kauppi, M., Kauppi, A., Accumulation of airborne elements from vehicles in transplanted lichens in urban sites. Journal of Environmental Quality 1996 (25) 265272.

[22] Hébrard-Labit. C et Meffray.L, Comparaison de méthodes d'analyse des éléments traces métalliques (ETM) et des hydrocarbures aromatiques polycycliques (HAP) sur les sols et les végétaux. Guide technique. CETE Nord Picardie (France) 2004, 121 p.

[23] Joumard R., Lamure C., Lambert J., Politiques de transport et qualité de l'air dans les agglomérations. LEN n 9515. Bron : INRETS (France) 1995, 125 p. 
[24] Kupper H, Lombi E, Zhao F J, Wieshammer G, McGrath S P., Cellular compartimentation of nickel in the hyperaccumulators Alyssum lesbiacum, Alyssum bertolonii and Thlaspi goesingense. Journal of Experimental Botany; 2001 (52), 2291-2300.

[25] Leblond. S. Etude pluridisciplinaire du transfert des métaux de l'atmosphère vers les mousses (Scleropodium purum (Hedw.) Limpr.) : Suivi sur un site rural (Vouzon, France). Thèse de doctorat en Chimie de la Pollution Atmosphérique et Physique de l'Environnement, Université Paris 7 - Denis Diderot 2004. 212p.

[26] Maatoug M. Détection de la pollution de l'air d'origine routière par certaines espèces végétales bioaccumulatrices de quelques métaux lourds ( $\mathrm{Pb}, \mathrm{Zn}, \mathrm{Cu}$ ). Revue pollution atmosphérique $2007 ; 196$ : 385-394.

[27] Maatoug M. Cartographie de la pollution atmosphérique par le plomb d'origine routière à l'aide de transplantation d'un lichen bioaccumulateur Xanthoria parietina dans la ville de Tiaret (Algérie). Revue pollution atmosphérique 2010 ; 205 : 93-101.

[28] Madany IM, Ali SM, Akhter MS. Assessment of lead in roadside vegetation in Bahrain. Environment International 1990 (16): 123-126.

[29] Ouzounidou G, Ciamporova M, Moustakas M, Karataglis S.,. Responses of Maize (ZeaMays L) Plants to Copper Stress .1. Growth, Mineral-Content and Ultrastructure of Roots. Environmental and Experimental Botany; 1995 (35), 167-176.

[30] Ouzounidou G, Moustakas M, Eleftheriou E P.,. Physiological and ultrastructural effects of cadmium on wheat (Triticum aestivum L) leaves. Archives of Environmental Contamination and Toxicology; 1997 (32),154-160.

[31] Peulon V., Le dépérissement des arbres en ville. Edition du STU, Ministère de l'Equipement (France) 1988, 61p.

[32] Semadi .A et Deruelle .S Détection la pollution plombique à l'aide de transplants lichéniques dans la région de Annaba (Algérie). Revue pollution atmosphérique Octobre-Décembre 1993 : 86-101.

[33] Vazquez M D, Poschenrieder C, Barcelo J., Ultrastructural Effects and Localization of LowCadmium Concentrations in Bean Roots. New Phytol; 1992 (120), 215-226. 


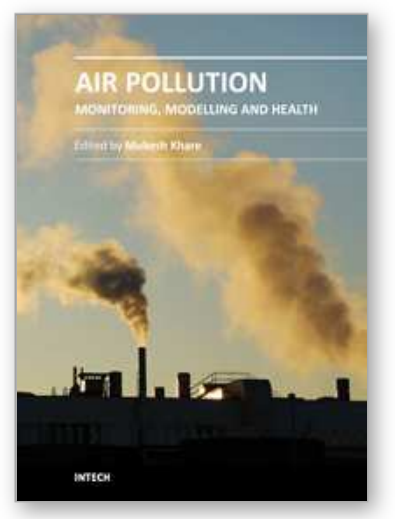

\author{
Air Pollution - Monitoring, Modelling and Health \\ Edited by Dr. Mukesh Khare
}

ISBN 978-953-51-0424-7

Hard cover, 386 pages

Publisher InTech

Published online 23, March, 2012

Published in print edition March, 2012

Air pollution has always been a trans-boundary environmental problem and a matter of global concern for past many years. High concentrations of air pollutants due to numerous anthropogenic activities influence the air quality. There are many books on this subject, but the one in front of you will probably help in filling the gaps existing in the area of air quality monitoring, modelling, exposure, health and control, and can be of great help to graduate students professionals and researchers. The book is divided in two volumes dealing with various monitoring techniques of air pollutants, their predictions and control. It also contains case studies describing the exposure and health implications of air pollutants on living biota in different countries across the globe.

\title{
How to reference
}

In order to correctly reference this scholarly work, feel free to copy and paste the following:

M. Maatoug, K. Taïbi, A. Akermi, M. Achir and M. Mestrari (2012). Bio-Monitoring of Air Quality Using Leaves of Tree and Lichens in Urban Environments, Air Pollution - Monitoring, Modelling and Health, Dr. Mukesh Khare (Ed.), ISBN: 978-953-51-0424-7, InTech, Available from: http://www.intechopen.com/books/air-pollutionmonitoring-modelling-and-health/bio-monitoring-of-air-quality-using-leaves-of-tree-and-lichens-in-urbanenvironments

\section{INTECH}

open science | open minds

\section{InTech Europe}

University Campus STeP Ri

Slavka Krautzeka 83/A

51000 Rijeka, Croatia

Phone: +385 (51) 770447

Fax: +385 (51) 686166

www.intechopen.com

\author{
InTech China \\ Unit 405, Office Block, Hotel Equatorial Shanghai \\ No.65, Yan An Road (West), Shanghai, 200040, China \\ 中国上海市延安西路65号上海国际贵都大饭店办公楼405单元 \\ Phone: +86-21-62489820 \\ Fax: $+86-21-62489821$
}


(C) 2012 The Author(s). Licensee IntechOpen. This is an open access article distributed under the terms of the Creative Commons Attribution 3.0 License, which permits unrestricted use, distribution, and reproduction in any medium, provided the original work is properly cited. 